\title{
No Easy Walk: Advancing Refugee Protection in South Africa
}

Jeff Handmaker

South Africa only began accepting individual applications for political asylum in 1994. A policy designed to recognize former Mozambican refugees for the purposes of a repatriation program became the (awkward) basis of the asylum procedure up until April 2000. Criticized by some, a lively discussion raising often-contradictory views began in 1996, leading to a policy reform process culminating in the Refugees Act in December 1998. The Act only came into force at the beginning of April 2000. This article analyzes the process of policy development in South Africa, focusing on practical and theoretical challenges facing the government in the implementation of the new Act. Special attention is given to temporary protection, the proposed containment of applicants in reception centers, the arbitrary manner in which asylum is currently determined, and inconsistencies between the interfacing of the Refugees Act and the proposed immigration legislation. The paper concludes by asserting that the new legislation can be effective, but only if the government builds capacity, and if the procedure allows a fair opportunity for asylum applicants to be granted a credible hearing.

\section{Introduction}

As the title of this essay suggests, it has been "no easy walk" ensuring adequate protection for refugees in South Africa. By all accounts this is a "walk" far from finished. While South Africa has certainly not been a stranger to refugee movements, particularly in its pre-1994 history, it only recently established an asylum determination regime to assess applications for refugee status on an individual basis. The development of a workable structure for administering the regime has been complicated by a number of factors, both policy- and capacity-related.

South Africa's policy on refugees has its origins in the country’s much-criticized Aliens Control Act (96 of 1991) (ACA), which in numerous respects has failed to provide adequate guarantees to applicants (Human Rights Watch 1998:170; Handmaker 1999a, 1999b). Until the recent implementation of its first-ever Refugees Act (Act 130 of 1998) in April 2000, South Africa's policy on refugees depended on the ACA, with the Department of Home Affairs responsible for enforcement. ${ }^{1}$ The ACA is an omnibus piece of legislation, with its origins in British colonial policies of the early twentieth century designed to restrict the 
number of immigrants to the Union, especially from India (Peberdy and Crush 1998). The contents and implementation of this Act have been roundly criticized, and its constitutionality seriously questioned (Klaaren 1996, 1998; Crush 1998; Klaaren and Sprigman 2000).

The asylum system has always fit quite uncomfortably within the country’s heavily criticized immigration regime (Klaaren and Sprigman 2000). There are not enough resources (especially staff) on hand to process the steadily increasing numbers of asylum applications. The number of applications appears to have stabilized in recent years and cannot be regarded as presenting a situation of "mass influx," compared with other countries on the continent (Handmaker 1999a:290). However limited the number of staff, the majority of whom urgently need training, make for a cumbersome system which has consistently failed to achieve satisfactory standards of administrative justice (Klaaren 1996; Kerfoot 2001).

This essay examines the process of refugee policy reform that began in 1996. This process led to the country's first-ever Refugees Act in 1998. The Act's accompanying regulations were only released one and a half years later in April 2000. More recently, the Chairperson of the Refugee Appeals Board released the first "Draft Rules” in June 2000, and the Ministry of Home Affairs proposed a Refugees Amendment Bill and accompanying explanatory Memorandum in 2001. ${ }^{2}$

This policy process has been extremely controversial, both in its making and in the final product, and it would be impossible to cover all aspects of this in a single essay (but see Handmaker, de la Hunt, and Klaaren 2001). This article focuses instead on several particularly contentious issues, notably temporary protection, repatriation, the proposal for containment of refugees in "reception centers," the arbitrariness of the refugee procedure as it currently operates, and conflicts between the new refugee regime and proposed migration policies. 


\section{Refugee Movements to South Africa}

While South Africa has only recently developed a policy on refugees and asylum, it has certainly been no stranger to displacement, generating and receiving substantial numbers of forcibly displaced persons in its history. One group of refugees consisted of those who fled South Africa as a consequence of persecution by the apartheid government. They lived in exile mainly in neighboring countries, but also further afield. A second group consisted of Mozambican refugees, victims of a destabilization campaign (economic as well as military) by South Africa, which directly resulted in the civil war in that country (Human Rights Watch 1998:24). These displaced persons settled (illegally) in the former "homeland" areas of South Africa (in particular Gazankulu and Kingwane). En route they faced great physical risks that included a lethal electric fence, heavily armed soldiers, and a wildlife reserve filled with dangerous animals (Human Rights Watch 1998:29).

After years of being systematically turned away, the UNHCR was finally permitted to establish a presence in South Africa in 1991. Once it gained a mandate to operate in South Africa, the UNHCR began addressing “durable solutions” for both the returning South African exiles, and an estimated 300,000 Mozambicans who had fled the civil war in their country, but had never been formally recognized by the South African government. While the return of exiles involved a burdensome program of reintegration, concerning in many cases the re-acquiring of South African citizenship, the problems facing the former Mozambican refugees proved to be even more complex.

To implement the program for former Mozambican refugees, the UNHCR facilitated the establishment of a tripartite commission, in cooperation with the governments of South Africa (represented by the Department of Home Affairs) and Mozambique (Handmaker 1999a:293). This Commission recommended two "solutions.” The first was for a repatriation program, to be implemented in terms of a “Tripartite Agreement” between the two 
governments and the UNHCR. This program was carried out under the auspices of the UNHCR as the coordinating agency. The second recommendation was for "regularized status” to be granted to the former Mozambican refugees. Approval for this program was finally granted by the South African cabinet in 1996. After extended delays, implementation began under somewhat controversial circumstances in February 2000 (Handmaker and Schneider 2002).

As the Mozambicans had never formally been recognized as refugees, it was necessary for them to be retrospectively "recognized" for the purposes of the time-limited repatriation program. Legal recognition was achieved through a basic determination procedure that was contained in Passport Control Instruction No. 20 of 1993, issued in terms of the Aliens Control Act. This procedure for establishing the refugee status of Mozambicans laid the basis for Passport Control Instruction No. 63 of 1994 which, together with other instructions and a "Basic Agreement” signed by UNHCR and South Africa, became the basis of South Africa's pre-1998 refugee policy (Handmaker 1999a:292-303).

The repatriation program failed to meet its own, modest goals (Dolan 1995), and was said by some to be the consequence of a "limited understanding of the pattern of refugees" own flight and return movements” (Wilson and Nunes 1994). The failure of the repatriation program to provide a "durable solution" to the majority of Mozambican refugees meant that they ended up once again in a "legal limbo." At the time the cessation clause for Mozambican refugees was put in place on 31 December 1998, this group was thought to comprise a significant proportion of the undocumented migrants living in South Africa (Human Rights Watch 1998:26).

Refugee movement to South Africa post-1990 has taken on a different character to the “mass influx” previously seen from Mozambique. Not long after the South African government introduced asylum determination procedures for individual applicants in 1993, a 
“trickle” of applicants began to arrive. The flow increased steadily between 1995 and 1998, later leveling off at approximately 20,000 per year (Figure 1 and Table 1). Asylum-seekers have come primarily from nearby countries such as Angola, and also from the Great Lakes area (Zaire (DRC), Burundi, and Rwanda) and the Horn (Sudan, Somalia, and Ethiopia). A smaller number have arrived from West African countries, mainly Nigeria and Senegal, though also Côte d’Ivoire, Cameroon, and other countries (Table 2). A larger number of applicants have been arriving from India and Pakistan. In June 2000, they made up eighteen percent of the total applications received, and thirty-one percent of applicants rejected (Table 3). Bearing in mind the current backlog, approved applications to date have overwhelmingly (eighty-eight percent) been from three countries perceived to be “refugee generating,” namely Somalia, Angola, and Zaire/Democratic Republic of Congo (Table 4).

While the reasons remain speculative, many in official circles hold the view that the majority of applicants are bogus, and have accordingly introduced a variety of restrictive policies. The latest of these policies restricts asylum-seekers from work or study. While there has undoubtedly been abuse of the system, the introduction of a "white list” has been resisted by NGOs who challenge the implicit assumption that any one country can be considered “safe,” particularly in relation to individuals targeted for persecution. Alternatively, there have been calls for an improvement in the efficiency of the Department of Home Affairs' management of the asylum determination procedure, which has so far led to incredibly long delays, and a substantial backlog in applications. In combination with a cumbersome, inefficient, and restrictive migration and immigration policy and implementation, this has led to a situation where migrants (many of whom are highly skilled) seek residence in South Africa through the asylum system, irrespective of whether they may be suffering persecution.

\section{Towards a Refugees Act: From Control to Protection}


The first proposal to introduce refugee legislation came about in 1996, with the preparation of an initial Draft Refugee Bill by the Department of Home Affairs (DHA) (Al-Omari 1996). This was followed by the circulation of a Second Draft Bill which received substantial critical commentary (de la Hunt 1996; Hathaway 1996; McNamara and Morjane 1996), and was the subject of a workshop in November 1996, organized by Lawyers for Human Rights, the Wits Refugee Research Program, and the South African Human Rights Commission. Various refugee rights advocates, the UNHCR, lawyers, academics, and senior representatives of the Department of Home Affairs attended the workshop, held at the offices of the Commission.

Civil society was at this stage beginning to get organized, having formed Refugee Forums in the provinces, and a Refugee Rights Consortium to lobby at the national level. The DHA also showed itself, at the outset, to be open to criticism and debate ${ }^{3}$ by its circulation of proposed policy documents, participation in the November 1996 Workshop, and other meetings with civil society representatives. Following the November Workshop, however, the departmental process was subsequently put on hold, pending the appointment of a Task Team by the Minister of Home Affairs. The Task Team produced a Draft Green Paper on International Migration in May 1997 (Republic of South Africa 1997). The Green Paper devoted a whole chapter to the refugee issue.

The Green Paper recommendations on refugee policy were heavily influenced by the work of the international Reformulation of Refugee Law Project. ${ }^{4}$ The proposals were commented on by various organizations and government departments, providing feedback from a wide range of perspectives that raised a number of substantive concerns. Particular attention was focused on the Green Paper's recommendations for temporary protection (discussed later in this article); it’s stated “solution-orientation” and proposals for "burdensharing” within the region (UNHCR 1997; Rutinwa 1997; Handmaker 1998, 1999a:299-304; Handmaker, de la Hunt, and Klaaren 2001). 
The Green Paper also recommended separate policy processes for migration and refugees. Despite pressures from civil society and a major conference in August 1997 organized by the Southern African Migration Project and the Parliamentary Portfolio Committee on Home Affairs, further progress was slow. This situation prompted Lawyers for Human Rights to organize a refugee policy conference in March 1998. Finally, in May 1998, the Department of Home Affairs appointed a Refugees White Paper Task Team.

The Task Team, which consisted of members from the Department, civil society and UNHCR, was provided with a Working Draft White Paper and Refugee Bill drafted by the DHA. This working draft of the bill closely resembled the problematic Second Draft Bill circulated in 1996, indicating that little progress had been made within the DHA in the interim. However, the White Paper Task Team was also under a mandate to draw reference from the recommendations of the Draft Green Paper, even though the government had made it clear in October 1997 that the document should only be considered for “discussion purposes.” In other words, the first process (which began in 1996 with the first Draft Refugee Bill) and the second process (beginning with the Green Paper) were finally consolidated into a single process.

A major difference at this stage in the policy process was that civil society organizations were now quite well organized. The National Consortium on Refugee Affairs (NCRA), a national network of South African NGOs (policy specialists, service providers, legal practitioners, and refugee representatives) and representatives from UNHCR and government (including the Border Police and the Department of Home Affairs) was founded in October 1997. By the time the Refugees White Paper Task Team was constituted, the NCRA had established a "legal affairs subcommittee," which organized at least two workshops and other, smaller meetings during the course of the Task Team's meetings. 
Several Task Team members were from organizations represented on the NCRA. Thus, it was possible to engage a larger body of input to the policy process.

Based on the recommendations of the Task Team, the DHA presented the Refugees White Paper to the public in a relatively short space of time on 19 June 1998 (Republic of South Africa 1998). The Department received public submissions, and the Task Team met again to consider them and make further amendments and recommendations to the Draft White Paper and Refugees Bill. These in turn were presented to the Parliamentary Portfolio Committee on Home Affairs. However, before the Committee received these documents, the State Law Advisors office extensively revised the Draft Bill, making changes to the refugee definition (which originally had repeated that contained in the International Conventions) and providing a more restrictive approach to determination. Again, the NCRA made extensive submissions, including a document of "joint concerns," presented to the Portfolio Committee in October of 1998.

The Portfolio Committee’s amendments to the Draft Bill eventually resulted in the Refugees Act being passed by a consensus of the National Assembly on 5 November 1998. Notwithstanding certain unresolved concerns over its content, it was encouraging to note the broad-based political support for the Bill, and to witness a much-needed legislative change, prior to the 1999 general election. Following assent by the Council of Provinces on 20 November, the Bill became law when President Nelson Mandela gave his signature on 2 December 1998. However, enthusiasm over the new legislation quickly turned to frustration, as the Act did not come immediately into force. Hence, the asylum determination regime continued to be administered in terms of the Aliens Control Act, with all of its accompanying problems (Klaaren 2000).

The Regulations to the Refugees Act were eventually issued by the Department of Home Affairs in April 2000. While the bringing into force of the Refugees Act was much 
welcomed, this was overshadowed by the contents of the Regulations themselves. These again raised concerns over implementation and the rights which refugees and refugee applicants ought to be entitled to, both during the course of the determination procedure, and following the granting of refugee status. The Refugee Appeals Board's Draft Rules, released in June 2000 were less contentious.

The list of enduring concerns still challenging the adequacy of refugee protection in South Africa is extensive. While the South African government deserves some praise for including a good representation of civil society organizations in the Task Team, the NCRA proved itself very effective in ensuring that many substantive policy concerns were addressed in the final legislation. But other concerns remain high on the agenda.

\section{Debates over Temporary Protection}

Temporary protection is an issue that first attracted major attention in the discussions around the Green Paper and has continued to generate critical debate, which has not always been very constructive, arising both out of conceptual misunderstanding and major differences in perspective. From the very beginning, there has been considerable political resistance in South Africa to refugee integration. The granting of refugee status has, since its inception, been temporary. Beginning with the former Mozambican refugees, it has always proved much easier (politically) to justify a program for refugee repatriation than one regularizing their status and integrating them into the South African community (Handmaker and Schneider 2002). Following the Mozambican repatriation program, and with the introduction of asylum determination procedures on an individual basis in 1994, it became quite clear that the government was reluctant to grant a more permanent status to refugees (Handmaker

1999a:299). However, the Refugees Act provided (in Section 27c) that a refugee: "is entitled to apply for an immigration permit ... after five years’ continuous residence in the Republic 
from the date on which he or she was granted asylum, if the Standing Committee certifies that he or she will remain a refugee indefinitely.”

This provision has yet to be fully tested, and is likely to prove controversial, not least because it is notoriously difficult to ascertain whether a refugee will remain so indefinitely, though situations that lead to refugee status rarely resolve themselves within a period of five years (Handmaker 1998:7, 1997:967).

The Green Paper insisted that it did "not endorse an understanding of refugee protection as an alternative means to immigrate permanently to South Africa” (4.2.2). No commentator fundamentally disagreed with this statement. However, some maintained that, notwithstanding inevitable abuse of the procedure, attempts to stay integration in all cases until after five years (given that a significant number already experienced long delays in the determination procedure) would be inhumane. Furthermore, such a measure would be contrary to domestic and international human rights standards (Handmaker 1999a:301-2). Others, including Rutinwa (1997, 2001), more generally questioned the viability of the general model proposed by the Green Paper. He claimed that "its elements were influenced by the negative attitudes of western states towards refugees after the cold war.” Rutinwa further questioned whether the Green Paper was, as it maintained, "rights regarding” (Rutinwa 1997:16).

Advocates of the Green Paper model, including Barutciski (1998), argued that such concerns relied on "false" comparisons with the application of temporary protection in Europe, which he said was "characterized by the absence of individualized status determinations because they involved perceived mass inflows. Protection was granted to groups deemed to require protection, rather than individuals determined to satisfy the criteria for refugee status” (Barutciski 1998: 713). 
However, Barutciski’s description of temporary protection in Europe actually very closely describes how asylum determination procedures operate in practice in South Africa. Despite the limited number of applications received, the government nevertheless seems to believe that the country is experiencing a "mass inflow," and has expressed its desire to introduce reception centers (see below). The government's concern appears to be related more to a seriously under-resourced department than anything else. Further, applications relating to individual persecution take many years to decide, and are often rejected on unsustainable grounds (Kerfoot 2000). It is now fairly well established that the large majority of positive decisions granting refugee status in South Africa are based either on assumptions of whether a country is "refugee generating" and falling within the broader OAU definition (van Beek 2001) or considered "safe." 5 Those involved with the Reformulation Project, which formed the basis of the model laid out in Chapter 4 of the Green Paper, maintain that there is no prohibition in the international refugee conventions against temporary protection, more particularly:

The temporary nature of the obligation to provide protection is most explicit in the permission the Convention grants states to revoke refugee status whenever there is effective and meaningful change in a refugee's country of origin, such that the need for protection no longer exists (Hathaway 1997b).

Barutciski (1998:705) alleges that arguing for the automatic integration of refugees is tantamount to advocating permanent residence for undocumented migrants. In one respect, this allegation can be rejected on the grounds that to acknowledge abuse of the asylum procedure cannot justify restrictive measures against all asylum applicants (Handmaker 1999a:301). That aside, those determined to abuse asylum procedures are in any event rarely deterred by measures which aim to diminish “pull” factors through punitive measures, as opposed to measures which address “root causes” (Ghosh 1998:147). The justification for this allegation perhaps stemmed from Barutciski’s later assertion that “limited rights apparently encourage a more liberal policy in situations of mass inflow, while elaborate rights 
that may lead to integration tend to discourage governments from allowing refugees to access their territories” (Barutciski 1998:714).

However, the asylum determination procedure in South Africa and, indeed, the rule of law in general, has for some time operated in a climate where rights entitlement (particularly prior to 1994) has traditionally been quite limited, and indeed is constantly being tested. Yet the asylum procedure has, by turns, become more and more restrictive. In other words, there has been no apparent "nexus” established in South Africa between a limited rights regime, and the liberalizing of asylum procedures. In fact, the primary issue that locally based commentators have been concerned with concerns the lack of basic administrative justice in the administration procedure itself (Klaaren 1996, 2000). In the absence of legal representation, it was urgently felt that the system needed to include adequate checks against administrative unfairness, since the consequences of a wrong decision in the procedure could very well amount to further persecution as rejected claimants were returned to their countries of origin (Kerfoot 2000).

A further argument put forward challenging the viability of "temporary protection" concerned the "psycho-social risk" to refugees, an aspect of protection that the Green Paper also acknowledged (Republic of South Africa 1997:4.6.7) but did not elaborate. In this sense, the period in which one's status in a country was uncertain could itself give rise to concern. Psychologists have concluded that a prolonged period of uncertainty in one's residential status can result in considerable psycho-social harm to refugees (Silove 1997).

In short, the question as to whether the Green Paper model of refugee protection would realistically address the concerns over the flaws in refugee protection in the existing system was seriously questioned on the grounds of existing administrative practice and human rights. While asylum determination in many crucial respects "mirrors" that of Europe, a major exception is that procedures in the north do tend to become more "visible" as they are more 
frequently challenged through the legal system. The reason for this is that applicants in the north are often granted legal representation, something which is nearly impossible in South Africa at the moment. From another perspective, some commentators rejected the temporary protection model proposed by the Green Paper, since it was clearly founded on the (unsustainable) assumption that protection for the duration of risk, followed by repatriation was necessarily the "best solution.”

It has been noted that "most refugee movements have tended to result in permanent exile of the displaced populations” (Rogge 1994). In recent years, the notion of repatriation as the "best solution" has been challenged, with some arguing that why refugees might want to return home is as important, if not more so, than how they return (Bakewell 1998). Others maintain that repatriations are often impossible to satisfactorily implement, since programs often ignore the causes which led to displacement in the first place (Voutira 1998). Finally repatriations and migrant return programmes are in many cases undertaken in circumstances where “conditions of absolute safety” are seriously questioned (Handmaker 1997). Even the UNHCR, which is traditionally very much in favor of repatriation as a solution, has recently advocated in favor of local integration, particularly for “urban-based” refugees (Geddo 2001).

In short, it is no longer realistic to assume that repatriation or return is the ideal solution, though there may well be occasions in which repatriation or return can be a viable solution, provided that programs are conducted in conditions of dignity and recognize certain practical obstacles (Handmaker 1999b). Such programs ought to at least benefit from past experience, recognizing that "repatriation is anything but problem free” (Rogge 1994:22).

\section{A Conflict Between “Reformulation” and Pragmatism?}

The disagreement over temporary protection and repatriation might best be explained as a dispute between those who endorsed a "reformulated" approach to refugee protection, as 
reflected in Chapter 4 of the Green Paper, and those who put forward pragmatic arguments grounded in the highly problematic local situation. Put another way, on one side there were those who advocated a model of refugee protection founded on an approach that it was better to liberalize refugee determination procedures, extending protection to a greater number of persons on a temporary basis (Hathaway 1997b and 2001; Barutciski 1998). On the other side, there were those who felt that the refugee procedure ought to be firmly rooted in the administrative and constitutional culture rapidly emerging in South Africa, and endorsed a “decentralized hearing-based system” (Klaaren and Sprigman 2000). This position was supported by others who felt strongly that the product of legislation ought to recognize the special "historical context," in which asylum procedures have been created and implemented (Handmaker 1999a:308). Still others felt more strongly that the model contained in Chapter 4 was "unsuitable for adoption" because it was "not informed by the experience of the region" (Rutinwa 1997:2).

Arguably the two strongest commentators on the temporary protection issue in South Africa have been Professor Jim Hathaway, now at the University of Michigan, and Dr. Bonaventure Rutinwa of the Centre for Forced Migration at the University of Dar Es Salaam, both of whom played very important roles in formal discussions on the process of refugee policy reform.

In his paper delivered at the March 1998 Refugee Conference, organized by Lawyers for Human Rights in Pretoria, Professor Hathaway acknowledged the concerns referred to above, by questioning whether temporary protection of refugees should be seen as a "threat or solution” (Hathaway 2001). Hathaway argued in favor of a "decisive and practical reinvigoration of refugee law,” for a more collective and “solution oriented” approach, and a more deliberate distinction between immigration and refugee protection. Hathaway further argued that "the refugee protection system was never intended to be a mechanism that 
generates solutions, but is instead a palliative regime that protects desperate people until and unless a fundamental change of circumstances makes it safe for them to go home.”

Arguing against “routine admission of all refugees to permanency,” Hathaway argued that such a view "holds refugees hostage to a major project of social transformation,” also stating that "the basic protective role of refugee protection should not be a captive" in debates over whether refugees ought to be entitled to permanent residence, which in South Africa he felt was "absolutist" in its orientation (Hathaway 2001). Hathaway felt that the model in Chapter 4 of the Green Paper was “seriously misunderstood.” Like Hathaway, Dr. Rutinwa also recognized the "crisis of the refugee protection regime," but is of a different view when it comes to resolving it. Rutinwa argued at the March 1998 Policy Conference that the rights of refugees under temporary protection have differed considerably from state to state, though clearly intend for refugees ultimately to be repatriated.

While acknowledging that the reformulation of refugee law project has made a "significant contribution" to debates on refugee policy, Rutinwa objected to the grounds and assumptions on which the "reformulation model" is based (Rutinwa 2001). In particular, Rutinwa took issue with the proposal for "collectivized” solutions, maintaining that its relevance is confined to only a few areas where refugee flows are focused, and that states will only cooperate “if the cost of noncooperation [is] higher” (Koser, Walsh, and Black 1998). More strongly, Rutinwa (2001) maintained that the effect of splitting fiscal and actual responsibility between (rich) northern and (much poorer) southern countries would amount to a "global apartheid” (Chimni 1998). In the end, both sides on the reformulation/pragmatist divide agreed that refugee protection ought to be provided to those who need it, yet there was substantial disagreement as to how, and especially at what cost, this was to be achieved. The 1998 Refugees Act attempts to steer a path between these conflicting views. 
Interestingly, a similar message came through at the Workshop on Temporary Protection at the Seventh IRAP Conference in South Africa on 7 January 2001. While the workshop focused largely on the operation of temporary protection in the European Union, it sought to clarify a number of issues concerning temporary protection generally, ranging from “definitions and approach” to “complementary protection of nonrefugees”.

While there were no concrete conclusions to the vigorous discussions that took place in the workshop, what emerged was an almost completely polarized debate between essentially two positions. On the one hand, there were those who felt that the future of refugee protection depended on a "principled” recognition that states were generally reluctant to offer refugee status to persons and would only do so under circumstances where refugees received a time-limited protected status; one of their arguments being that if there was a "guarantee of quality, how would non-permanency offend?” On the other hand, there were those who resisted the imposition of temporary protection as a matter-of-course on the grounds that such a status was dangerously insecure and that it was pressuring states to repatriate. In their view, states' reluctance to extend refugee protection to those who need it has long been a problem requiring constant vigilance and advocacy, and one that would not be resolved by a "political buy-in.”

\section{Containment: Proposed Reception Centers}

Section 35(1) of the Refugees Act allows for the designation of “areas, centres or places” for the temporary reception of asylum-seekers or refugees in situations of “mass influx.” In 1999, the Department of Home Affairs released a “Discussion Document” to civil society organizations and UNHCR, proposing the establishment of "Reception Centres," where asylum-seekers would be required to stay while their applications for asylum were being processed (Department of Home Affairs 1999). This document was informed by a desire to 
“curtail rampant corruption, crime, and abuse, that have made the refugee program in South Africa a backdoor for illegal migration by persons seeking primarily economic betterment.” The government went on to say that "it is therefore understood that decisive measures should be taken, consistent with international refugee law and protection principles, to curb such abuse and restore the credibility of the institution of asylum” (Department of Home Affairs 1999:1).

Ostensibly, the proposal aims to reduce the "pull factors,” which allegedly cause irregular migration to the country. This approach is consistent with the proposal in the White Paper on International Migration (Republic of South Africa 1999:4.2.1) that the government could "prevent illegal migration” by "reducing pull factors" through punitive measures, an approach described recently by a leading commentator as quite ineffective in stemming the flow of irregular migration (Ghosh 1998).

The intention of the government was to get civil society organizations to endorse this proposal, with the view to have centers established in far-off, rural areas (van Garderen 1999b:14). Instead, the proposal has faced strong resistance, particularly from human rights organizations who feel that the project is not feasible, not least on economic grounds (van Garderen 1999a:3). It is also felt that the establishment of centers would "have serious implications on some of the fundamental rights currently enjoyed by asylum-seekers.” From an administrative law point of view, the main contention against centers has been that the provision of the Act ought only to be used in circumstances of a sudden "mass influx" (van Garderen 1999a:3) which, in the current situation, is clearly not the case.

\section{Discussion Document, 1999}

The Discussion Document requires that there be a "maximum delay of four months" (Department of Home Affairs 1999:4). However, as commentators have noted (Dutch 
Refugee Council 1997; van Garderen 1999a:3; Jenkins and de la Hunt 2000), the period of time in which one is normally confined to a reception center, which is dependent on the efficiency of the asylum determination procedure, is very often longer. It is very common for asylum-seekers to be in such centers for one year, or even longer, as it is inextricably linked to (often lengthy) asylum procedures (Dutch Refugee Council 1997:3). Freedom of movement concerns and financial considerations aside, given the current state of the asylum determination procedure in South Africa (where decisions can take up to three years) it would not seem advisable (even in terms of the Department's own, stated principles) to introduce reception centers.

\section{Arbitrariness in the decision-making process}

As many commentators have noted, the asylum determination procedure in South Africa is characterized by a high degree of arbitrariness, which fails to achieve acceptable standards of administrative justice (Klaaren 1996; Handmaker 1999a:295; Klaaren and Sprigman 2000; Kerfoot 2000). Applications tend to be decided favorably with regard to the general conditions in certain countries perceived as "refugee generating," or rejected on the grounds that conditions are perceived as "safe" - in other words on a "group" basis, rather than on individual assessment (van Beek 2001; Klaaren 2000). Indeed, eighty-five percent of positive decisions on applications are being decided in favor of three countries, namely Angola, (former) Zaire, and Somalia, while only 141 applications out of 5,000 from Somalians have been rejected outright or declared manifestly unfounded as of April 2001. At the same time, the majority of rejected applicants have been from four countries: India, Senegal, Pakistan, and Nigeria.

Concerns over administrative justice have been central to the concerns of a number of refugee groups and practitioners, who are firmly of the view that consideration of country 
situations in general provides more persuasive criteria in making determinations than the individual experiences of asylum-seekers (Kerfoot 2000). While there have been few lawyers in South Africa able, let alone willing, to take up the cases of asylum applicants who claim their rights have been infringed, the few cases which have reached the courts have established important precedents (Kerfoot 2000).

Other concerns over the procedure include: the interviewing process (including the absence of qualified translators); inadequate access to country information; and the sheer lack of staff available to conduct interviews and make determinations. These are in most respects resource and training issues which need to be urgently corrected. However, the structure of the procedure itself causes serious problems, up to and including the appeals procedure. This is a policy question. In order to address this, two approaches towards asylum determination have been recommended. One approach, recommended by the Green Paper, argued for a “streamlined, one-step investigatory status determination procedure” (Republic of South Africa 1997: 4.4.2), endorsed by those who favored a "reformulation" of refugee law. The other approach, endorsed by locally based organizations, favored a "hearings-based" determination procedure (Klaaren and Sprigman 2000). Ultimately, the Refugees Act adopted the latter, yet it remains to be seen how this will operate in practice.

\section{Refugees Amendment Bill 2001}

The 1999 Discussion Document has since been superseded by a proposed Refugees Amendment Bill, released at the beginning of 2001 along with an explanatory "Memorandum.” The Bill aimed to do two things: firstly to provide a legislative framework for the introduction of government-run Reception Centers for asylum-seekers in South Africa and, secondly, to introduce legal mechanisms for the purposes of restrictively interpreting the extension of refugee status in terms of the Refugee Act 1998. 
It is abundantly clear that the amendments proposed by this Bill would not only fail to stand up to a constitutional challenge, but would violate fundamental principles of international law. Indeed, one of the restrictive mechanisms proposed, namely the Department of Home Affairs’ erstwhile policy of refusing admission to asylum applicants who passed through a purportedly “safe third country,” was recently (and successfully)

challenged by way of a legal case taken up by Lawyers for Human Rights in May $2001 .^{6}$ Soon afterwards, the Minister of Home Affairs publicly called the Director General to task for “implementing a legally questionable asylum policy without his knowledge”. 7

Thus, judging by recent events, the proposal to introduce reception centers for asylumseekers in South Africa will at the very least be delayed for some time. It is hoped that South Africa will take due warning of the dreadful experience of compulsory detention of asylumseekers in other countries and scrap the idea altogether, an idea which, in the opinion of two researchers who have comprehensively researched the subject, "would constitute the fourth successive trauma” experienced in South Africa (Jenkins and de la Hunt 2000:63).

\section{Contradictions Between Refugee and Migration Policy}

The Draft White Paper on International Migration was released in April 1999, nearly two years after the Green Paper was produced. It was followed in February 2000 by a Draft Immigration Bill. Even though the Green Paper specifically recommended separate White Papers for refugees and migration generally (Republic of South Africa 1997:1.5.7), and the White Paper indicated that it "would not deal with the issue of refugees" (Republic of South Africa 1999:3.3), it was clear that refugees would be affected by the migration policy, particularly the provisions on border control (Handmaker 1999c:4).

The White Paper dwells at some length on the concept of the "community,” though the term is not specifically defined. By implication, it appears to be a "citizen-based” concept, 
calling on South Africans to understand the distinction between different types of foreigners and tolerate, perhaps even to accommodate, but not integrate "noncommunity" members (Handmaker 1999c:4). Further, the White Paper calls on the "community” to assist in the enforcement of the country's migration control systems, suggesting that one would be a "good citizen” by reporting anyone suspected of being without legal residence to the authorities. In the words of the White Paper, the "community" would be "responsible for cooperating with internal policing actions to ensure that illegal immigrants are not attracted to South Africa” (Republic of South Africa 1999:4.4.1).

The White Paper drafters clearly anticipated that such administrative separation might cause some tensions, and thus further proposed that public education programs be undertaken on xenophobia. As the White Paper put it, one of the government's priorities would be "ensuring that education is provided at community level to avoid any form of xenophobia by making communities understand the tragedy of illegal immigration while co-operating with law enforcement authorities” (Republic of South Africa 1999:6.5).

Apart from the proven ineffectiveness of such punitive approaches to border control (Ghosh 1998:147), concerns over xenophobia are becoming ever more pressing. Refugees and other migrants in South Africa have, in recent years, been subject to multiple attacks on xenophobic grounds, some instances of which have received considerable attention (Human Rights Watch 1998). ${ }^{8}$ It is unlikely that this approach will do anything to stem the rise in xenophobia, particularly with regard to refugees who because of linguistic, cultural, and other differences tend to be far more visible than other migrants. If anything, such an approach will split “communities” further and exacerbate the current levels of xenophobia, perhaps even leading to a new kind of “vigilantism” (Lawyers for Human Rights 1999:4).

A significant criticism of the proposed policy and the Draft Immigration Bill was that it effectively brings refugee protection "back within the ambit of migration control,” rather 
than distinguishing between the two (Klaaren 2000). In the case of general border control issues this distinction is certainly important, yet of more limited direct consequence. In terms of the asylum determination regime and the migration regime, such a distinction is very important indeed. Both the White Paper and Immigration Bill delved further into issues specifically affecting refugees than they should have. The Bill even insists that it take "precedence" over the Refugees Act in the event of conflict (Republic of South Africa 2000:Schedule 3).

In this regard, inconsistencies between the Refugees Act and the Immigration Bill become highly relevant. For example, the White Paper and the Immigration Bill both refer to “repatriation,” a term in international law with specific legal meaning attached to refugees (as opposed to migrants in general). Indeed, respected commentators have stressed that (voluntary) repatriation carries with it a responsibility on the part of the international community to find solutions for refugees, while at the same time ensuring that the "interests of individuals and communities” are not disregarded (Goodwin-Gill 1996:271).

\section{Conclusion}

Politicians in South Africa have been criticized for using the broader issue of migration for political gain (Human Rights Watch 1998:123). Whatever criticisms one might levy against the government, it cannot be denied that politicians face considerable policy hurdles, which have yet to be overcome, coupled with an administration that is currently incapable, both in terms of numbers and training, of handling the (gradually) rising number of asylum applications.

Migration policies that have their origins in the government's attempts to exclude certain categories of persons will have little constructive effect in stemming the flow of migrants. Rather, an inclusive approach towards categories of persons whose skills are so 
urgently needed in South Africa, and a recognition of the "circular" nature of much contemporary migration, will go a long way towards redressing the negative trends of the Aliens Control Act, which have so often led to acrimony between civil society and government, rather than a constructive discussion of possible solutions.

With regard to refugees, it can be argued that differences of opinion and perspectives among various civil society commentators have played a role in stimulating the search for a practical, efficient, yet rights-respecting determination procedure. There is nevertheless a real need for additional research. The principle of refugee protection is, as the government rightly states, derived from constitutional and international obligations. Indeed, this principle ought to ensure the integrity of refugee protection over and above considerations on migration in general. But there is a moral imperative as well, and distinguishing the justification for a fair and rights-regarding procedure on the basis of "principle" rather than "goodwill” is difficult to sustain in the current global climate, when the need for protection from human rights violations is as urgent as it as ever been. ${ }^{9}$

\section{NOTES}

1. The Department of Home Affairs carries a great deal of "institutional baggage." Previously, the Department was responsible for enforcing the notorious "pass laws" and “Group Areas Act,” key features of the previous government’s policy of apartheid.

2. Draft Refugee Affairs Appeal Board (Procedure) Rules 2000 are available at www.lhr.org.za/refugee/appboard.htm

3. This situation, unfortunately, changed following the deliberations of the Green Paper Task Team. The policy debate was effectively “stalled” until May 1998.

4. The Reformulation of Refugee Law Project was funded by the Ford and MacArthur Foundations and based for its duration at the Centre for Refugee Studies, York University, Canada; see Hathaway (1997a, 1997b). Professor James Hathaway of York University was a consultant to the Green Paper Task Team.

5. The 1969 OAU Convention on the specific aspects of refugee problems in Africa provides a broader definition of a refugee, extending to situations '...owing to external aggression, occupation, foreign domination or events seriously disturbing public order...", Art. I(2), 1000 
UNTS (United Nations Treaty Series) 46; South Africa acceded to this Convention on 15 December 1995. This trend appears to be leading to the creation of a "white list" of countries. In the words of the Deputy Minister of Home Affairs, "We will draw up a list of countries we recognize as democracies, and we expect that people from those countries won't need to come to SA as refugees," Cape Times, 19 April 2000.

6. LHR v. Minister of Home Affairs, Case No.10783/2001, Pretoria Local Division.

7. 'Buthelezi accuses Masetlha’, Business Day: Johannesburg, April 252001

8. One particularly publicized incident concerned the murders of three asylum-seekers, on a train between Johannesburg and Pretoria. See: “Train from hell to Irene Station,” Pretoria News, 4 September 1998. Subsequent articles were critical of the public's response, including "Public accused of being soft on mob killings," Sunday Independent (SA), 6 September 1998. This incident was also reported in the international press, including the UK Independent on Sunday, "Xenophobic South Africa shrugs off train murders," 13 September 1998.

9. On the day the Refugees Act was passed through South Africa's parliament, the Deputy Minister of Home Affairs made clear that: "When we give asylum to refugees, we do so because of our constitutional and international obligations. We do so as a matter of principle, not as matter of goodwill, and we are not doing anyone a favor" (Hansard, Proceedings of Extended Public Committee - Chamber of the National Assembly, 5 November 1998, at page 7751, South Africa.)

\section{REFERENCES}

Al-Omari, Ghaith. 1996. Comments on the South African Refugees Act 1994 (working draft). Unpublished paper. Oxford: Refugee Studies Programme, University of Oxford.

Bakewell, Oliver. 1998. Repatriation and Self-settled refugees in Zambia: Bringing solutions to the wrong problems. Paper presented at the 6th IRAP Conference, 13-16 December 1998.

Barutciski, Michael. 1998. The Development of Refugee Law and Policy in South Africa: A Commentary on the 1997 Green Paper and 1998 White Paper/Draft Bill. International Journal of Refugee Law 10(4):700-24.

Chimni, B.S. 1998. The Geopolitics of Refugee Studies: A View from the South. Journal of Refugee Studies 11(4):350-74.

Crush, Jonathan, ed. 1998. Beyond Control: Immigration and Human Rights in a Democratic South Africa. Cape Town and Kingston: Idasa and Southern African Migration Project.

de la Hunt, Lee Anne. 1996. Comments on the Second Draft of the Refugees Bill. Unpublished paper. Cape Town: University of Cape Town Law Clinic. 
1998. Refugees and Immigration Law in South Africa. In Beyond Control:

Immigration and Human Rights in a Democratic South Africa, edited by Jonathan Crush. Cape Town and Kingston: Idasa and Southern African Migration Project.

Department of Home Affairs. 1999. Discussion Document on the Proposed Reception Centres for Asylum-seekers in South Africa. Pretoria: Government Printer.

Dolan, Chris. 1995. Report to the Norwegian Refugee Council by the Wits Rural Facility Refugee Research Programme. Oslo: Norwegian Refugee Council.

Dutch Refugee Council. 1997. Asylum-seekers — don't let them just sit and wait. Amsterdam: Dutch Refugee Council and The Pharos Foundation.

Geddo, Bruno. 2001. Durable Solutions to the Refugee Problem: UNHCR'S Regional Strategy for Southern Africa. In Perspectives on Refugee Protection in South Africa, edited by Jeff Handmaker, Lee Anne de la Hunt, and Jonathan Klaaren. Pretoria: Lawyers for Human Rights.

Ghosh, Bimal. 1998. Huddled Masses and Uncertain Shores: Insights into Irregular Migration. The Hague: Kluwer Law International.

Goodwin-Gill, Guy S. 1996. The Refugee in International Law. Oxford: Clarendon Press.

Gordimer, Nadine. 1991. The Ultimate Safari. In Crimes of Conscience. London: Heinemann.

Handmaker, Jeff. 1997. Is it safe to return? West Africa 4154:967.

1998. Refugees, Migrants, Immigrants and Policy Development: A Critical Look at the South African 1997 Draft Green Paper on International Migration. Unpublished paper. Pretoria: Lawyers for Human Rights.

- 1999a. Who Determines Policy: Promoting the Right of Asylum in South Africa. International Journal of Refugee Law 11(2):290-309.

. 1999b. Returning Home: Learning Lessons From the Past, and Promoting Safety and Dignity in Repatriation and Return. Africa Legal Aid Quarterly 3:19-27.

— 1999c. Refugees and the 'Community': A Preliminary Review of the White Paper on International Migration. Botshabelo 2(2).

Handmaker, Jeff, Lee Anne de la Hunt, and Jonathan Klaaren, eds. 2001. Perspectives on Refugee Protection in South Africa. Pretoria: Lawyers for Human Rights.

Handmaker, Jeff and James Schneider. 2002. The Status ‘Regularisation’ Program for Former Mozambican Refugees ("FMRs”) in South Africa. Unpublished paper. Submitted for publication in February 2002.

Hathaway, James and Neve, Alexander. 1996. Comments from the Perspective of International Refugee Law. Unpublished paper. Cape Town: Southern African Migration Project. 
Hathaway, James. 1997a. Making International Law Relevant Again: A Proposal for Collectivized and Solution-Oriented Protection. Harvard Human Rights Journal 10:115-211.

, ed. 1997b. Reconceiving International Refugee Law. The Hague: Martinus Nijhoff.

- 2001. Temporary Protection of Refugees: Threat or Solution? In Perspectives on Refugee Protection in South Africa, edited by Jeff Handmaker, Lee Anne de la Hunt, and Jonathan Klaaren. Pretoria: Lawyers for Human Rights.

Human Rights Watch. 1998. "Prohibited Persons": Abuse of Undocumented Migrants, Asylum-seekers, and Refugees in South Africa. New York: Human Rights Watch.

Jenkins, Frankie and Lee Anne de la Hunt. 2000. Detaining Asylum-seekers: Perspectives on Reception Centres for Asylum-seekers in South Africa. National Consortium on Refugee Affairs, South Africa, September.

Kerfoot, William. 2000. The Lack of Due Process in Asylum Determination in South Africa. Paper presented at Conference on Refugees in the New South Africa, Pretoria.

Klaaren, Jonathan. 1996. So Far Not So Good: An Analysis of Immigration Decisions Under the Interim Constitution. South African Journal on Human Rights 12:605-616.

-1998. Immigration Law and the South African Constitution. In Beyond Control: Immigration and Human Rights in a Democratic South Africa, edited by Jonathan Crush. Cape Town and Kingston: Idasa and Southern African Migration Project.

- 2000. Refugee Policy and Law in South Africa. Workshop on Forced Migrants in the New Millennium, University of Western Cape, Cape Town.

Klaaren, Jonathan and Chris Sprigman. 2000. Refugee Status Determination Procedures in South African Law. Paper presented at Conference on Refugees in the New South Africa, Pretoria.

Koser, K., M. Walsh, and R. Black. 1998. Temporary protection and the Assisted Return of Refugees from the European Union. International Journal of Refugee Law 10(3):44461.

Lawyers for Human Rights. 1999. Comments on the White Paper on International Migration. Pretoria: Lawyers for Human Rights.

McNamara, Dennis and Kemal Morjane. 1996. Comments on South Africa Draft Refugees Bill. Unpublished paper.

National Consortium on Refugee Affairs. 1998. Summary of Concerns of the National Consortium on Refugee Affairs (NCRA), Draft Refugees Bill 1998: Version Reviewed by the State Law Advisors. Unpublished paper. 
Peberdy, Sally and Jonathan Crush. 1998. Rooted in Racism: The Origins of the Aliens Control Act. In Beyond Control: Immigration and Human Rights in a Democratic South Africa, edited by Jonathan Crush. Cape Town and Kingston: Idasa and Southern African Migration Project.

Republic of South Africa. 1997. Green Paper on International Migration. Government Gazette 383(18033). Notice 849 of 1997. Pretoria: Government Printer.

— 1998. Draft Refugee White Paper. Government Gazette 396(18988). Notice 1122 of 1998. Pretoria: Government Printer.

1999. White Paper on International Migration. Government Gazette 416(19920). Notice 529 of 1999. Pretoria: Government Printer.

—. 2000. Draft Immigration Bill. Government Gazette 416(20889). Notice 621 of 2000. Pretoria: Government Printer.

Rogge, John. 1994. Repatriation of Refugees. In When Refugees Go Home: African Experiences, edited by Tim Allen and Hubert Morsink. Trenton, New Jersey: Africa World Press.

Rutinwa, Bonaventure. 1997. The Conceptual Basis and Practicability of the Chapter on Refugees in the South African Green Paper on International Migration. Unpublished paper.

2001. Temporary Protection and its Expression Under the 'Reformulation of Refugee Law' Model. In Perspectives on Refugee Protection in South Africa, edited by Jeff Handmaker, Lee Anne de la Hunt, and Jonathan Klaaren. Pretoria: Lawyers for Human Rights.

Silove, Derrick. 1997. Anxiety, Depression and PTSD in Asylum-Seekers: Associations with Pre-Migration Trauma and Post-Migration Stressors. British Journal of Psychiatry 170(4):351-7.

South African Human Rights Commission. 1999. Report on the Apprehension and Detention of Suspected Undocumented Migrants. Johannesburg: SAHRC.

United Nations High Commissioner for Refugees. 1997. Comments on Chapter 4 of the Draft Green Paper on International Migration. Unpublished paper. Pretoria: UNHCR.

van Beek, Ingrid. 2001. Prima Facie Asylum Determination in South Africa. In Perspectives on Refugee Protection in South Africa, edited by Jeff Handmaker, Lee Anne de la Hunt, and Jonathan Klaaren. Pretoria: Lawyers for Human Rights.

van Garderen, Jacob. 1999a. Editorial. Botshabelo 2(3):3. . 1999b. Introducing Reception Centers. Botshabelo 2(3):14. 
Voutira, Eftihia. 1998. Refugee Integration in Receiving Countries: Lessons From the Past and Contemporary Challenges. Paper presented at Conference on Refugees in the New South Africa, Pretoria.

Wilson, K.B. and J. Nunes. 1994. Repatriation to Mozambique. In When Refugees Go Home: African Experiences, edited by Tim Allen and Hubert Morsink. Trenton, New Jersey: Africa World Press. 